\title{
PENERAPAN METODE AHP UNTUK SUBSISTEM PENDUKUNG PEMILIHAN SUPPLIER PADA OUTHOUSE COSTING INTEGRATED SYSTEM (OCIS) DI PT ADM
}

\author{
Surja Surjandy; Melva \\ Information System Department, School of Information Systems, BINUS University \\ Jln. K.H. Syahdan No. 9, Palmerah, Jakarta Barat 11480 \\ surjandy@gmail.com,melvaisme@yahoo.com
}

\begin{abstract}
In general automotive development, especially car, PT Astra Daihatsu Motor (ADM) continuously improves quality and service to supply vehicles in Indonesia. To support the improvement of quality and service, PT ADM continues to improve technology-based system to assist in providing vehicle parts of production process requirements. Therefore Purchasing division is very important in this process. Besides, supplier is a very important role in making and supplying parts for the company. PT ADM has a new system used to improve bidding process. Based on the discussion, price was not the only thing significant. There were other things to consider, especially in selecting the right supplier. Realizing the system does not cover all areas, therefore, it needs Decision Support System with AHP method to filter suppliers. So that, the company will automatically have good supplier. At least, the supplier meets company standard, especially purchasing department. This research concludes that using AHP Method is very effective for filtering supplier so that the company can make sure that only capable supplier or supplier which meets company standard may join the tender to supply the goods or parts. This paper combined AHP Methodology as the first selection using pairwise scoring and Analysis Sensitivity Methodology used to take decision which supplier is in line with project requirements.
\end{abstract}

Keywords: DSS, AHP, Purchasing

\begin{abstract}
ABSTRAK
Dalam perkembangan dunia automotif secara umum dan mobil secara khusus, PT Astra Daihatsu Motor (ADM) terus meningkatkan kualitas dan pelayanan dalam penyediaan kebutuhan kendaraan di Indonesia. PT ADM terus meningkatkan system berbasis teknologi agar mempercepat proses penyediaan kebutuhan part kendaraan untuk kebutuhan proses produksi. Oleh karena itu, divisi Purchasing menjadi divisi yang sangat berperan penting dalam menyiapkan kebutuhan part. Selain itu, Supplier menjadi hal yang juga berperan sangat penting sebagai pihak yang membuat dan penyedia part bagi PT ADM. PT ADM memiliki sistem yang digunakan untuk membantu mempercepat proses bidding. Namun dari diskusi yang dilakukan, didapatkan bahwa bukan hanya nominal atau angka atau harga yang menjadi peran penting. Ada hal lain yang harus diperhatikan, terutama untuk pemilihan supplier yang tepat dan cepat. Menyadari adanya kekurangan dari sistem yang ada, maka untuk membantu melengkapi sistem yang telah dimiliki, subsistem yang dapat menilai kemampuan atau spesialisasi tiap supplier dibutuhkan. Subsistem tersebut ditambahkan dengan Decision Support System dengan metode AHP, mulai tahap awal pemilihan supplier hingga secara otomatis terpilih supplier yang sesuai dengan kebutuhan perusahaan, khususnya divisi Purchasing. Berdasarkan penelitian, disimpulkan bahwa metode AHP sangat efektif dalam melakukan filterisasi terhadap supplier dan sehingga hanya Supplier yang memiliki bobot atau standar sesuai dengan perusahaan yang dapat mengikuti tender penyediaan barang atau parts. Paper ini menggabungkan metode AHP sebagai seleksi awal dengan melakukan pembobotan/scoring dengan cara pairwise dan Analisis Sensitivitas untuk mendapatkan keputusan supplier yang dibutuhkan sesuai dengan proyek yang ada.
\end{abstract}

Kata kunci: DSS, AHP, Purchasing 


\section{PENDAHULUAN}

Perkembangan teknologi informasi dan komunikasi memberikan dampak yang sangat besar bagi semua bidang. Salah satu bidang yang banyak terkait menggunakan pemanfaatan teknologi informasi dan komunikasi adalah bidang usaha. Setiap bidang usaha atau perusahaan berlomba-lomba untuk menerapkan teknologi informasi dan komunikasi yang terbaru agar menjadi yang terbaik. Atau dapat dikatakan, teknologi informasi dan komunikasi adalah sebagai alat untuk memenagi persaingan usaha. Hal ini juga berlaku pada perusahaan yang bergerak dalam bidang manufaktur. Perkembangan dan persaingan yang makin meningkat di antara perusahaan tersebut menimbulkan terjadinya kompetisi di antara perusahaan, tidak terkecuali dengan penerapan teknologi informasi dan komunikai yang dimiliki masing-masing perusahaan. Setiap perusahaan mulai menginvestasikan teknologi informasi atau sistem informasi karena diharapkan memberikan keunggulan dibandingkan perusahaan lain. PT Astra Daihatsu Motor (ADM) merupakan salah satu perusahaan manufaktur (pemegang merek dan perakitan kendaraan) di Indonesia yang memproduksi mobil dengan merek dagang Daihatsu dan Toyota. PT ADM didirikan pada 31 Mei 1978 dengan visi menjadi No. 1 di pasar mobil compact di Indonesia dan sebagai basis utama produksi global untuk group Daihatsu/Toyota yang sama dengan standar kualitas pabrik Jepang. Saat ini volume produksi dari tahun ke tahun makin tinggi. Pada akhir 2012 kapasitas produksi ditargetkan mencapai 450.000 unit.

Dalam usaha mencapai tujuan yang telah ditentukan, PT ADM membutuhkan kinerja yang baik dari komponen-komponen penyusun kegiatan bisnis baik yang terkait dengan pihak internal maupun pihak eksternal. Supplier merupakan salah satu pihak eksternal yang menjadi pendukung utama kegiatan bisnis PT ADM. PT ADM memiliki satu divisi yang mengurusi berbagai kegiatan bisnis yang terkait dengan supplier, divisi tersebut adalah divisi Purchasing. Penelitian menitikberatkan pada pencarian supplier yang tepat sesuai dengan kebutuhan proyek dan yang memenuhi standar perusahaan agar kualitas barang dan kelangsungan stok barang dapat dipenuhi. Penggunaan metode AHP menjadi sangat tepat sehingga harapan dari penelitian ini dapat dipenuhi dan dipercepat. Filterisasi dapat dilakukan pada saat supplier melakukan pendaftar pada sistem. Dengan demikian, walaupun banyak supplier yang mendaftar, hanya yang memiliki bobot atau kriteria yang diinginkan oleh perusahaan yang dapat mengikuti tender atau masuk pada fase berikutnya. Agar metode AHP dapat diimplementasikan dengan tepat, parameter atau variabel yang dibutuhkan sebagai faktor penentu harus dilakukan dengan tepat. Dengan hasil angket dan wawancara dari orang orang yang memiliki kompetensi dalam bidang ini, variabel tersebut dapat ditentukan.

\section{Identifikasi Permasalahan}

Pada divisi Purchasing beberapa kegiatan berfokus mencari dan menentukan supplier yang akan bekerja sama untuk menyediakan part yang dibutuhkan perusahaan untuk mendukung proses produksi yang ada di PT ADM. Berbicara mengenai pemilihan supplier, proses real yang dilakukan untuk menentukan supplier yang dipilih untuk menyediakan part masih dilakukan secara manual. Proses pemilihan supplier dilakukan dengan melihat sisi kualitas, sisi pengiriman, penawaran harga yang diberikan supplier melalui quotation, serta faktor - faktor lain yang sudah menjadi 'habit' di divisi purchasing pada saat pemilihan supplier. Melihat kondisi pemilihan supplier yang terjadi di divisi purchasing PT ADM, bisa disimpulkan bahwa ADM belum memiliki sistem dapat membantu divisi purchasing untuk menentukan supplier yang berhak dan memiliki kriteria yang tepat untuk dapat menyuplai part guna mendukung proses produksi di PT ADM. Faktor penentu dalam pemilihan supplier seperti QCD (Quality Control Departement), harga, atau faktor lain belum dirumuskan dalam satu struktur pemilihan supplier yang jelas.

PT ADM saat ini sudah memiliki aplikasi OCIS (Outhouse Costing Integrated System) yang digunakan untuk membantu proses komputerisasi dari dokumen price agreement (dokumen persetujuan harga). Dengan demikian, history harga dari keseluruhan part dapat diakses menggunakan 
OCIS. Selain itu, OCIS juga sudah digunakan untuk menyimpan data quotation dari supplier yang sudah terpilih untuk menyuplai suatu part. Sehingga, ketika supplier ingin melakukan perubahan harga, maka supplier tidak perlu lagi mengirimkan hardcopy quotation. Pada kenyataannya, penggunaan OCIS masih berhenti pada proses penyimpanan semua history dokumen yang dibutuhkan di divisi Purchasing dan sebagai databasequotation untuk pengadaan part yang sudah berjalan. Namun untuk supplier baru, yang ingin mengikuti proses bidding pengadaan suatu part, masih harus mengirimkan hardcopy quotation. Permasalahan yang lain adalah kriteria yang menjadi dasar untuk penentuan supplier belum dibentuk menjadi satu kesatuan dengan penawaran harga yang ada di quotation (masing - masing masih berdiri sendiri). Pemilihan supplier dengan kondisi seperti ini memakan banyak waktu dan hasilnya pun bersifat subjektif.

Melihat kondisi pemilihan supplier yang masih dilakukan secara manual dan penggunaan OCIS yang hanya terfokus pada penyimpanan history data purchasing, maka penulis hendak merancang suatu sistem yang nantinya dapat membantu divisi purchasing untuk memilih supplier berdasarkan setiap kriteria yang jelas dan terstruktur dengan waktu yang singkat. Oleh karena itu, disepakati untuk menjadikan "Pemaksimalan Penggunaan Outhouse Costing Integrated System (OCIS) dengan Pembuatan Subsistem untuk Mendukung Pemilihan Supplier di PT Astra Daihatsu Motor". Dari hasil wawancara yang dilakukan dan dengan disadarinya keterbatasan sistem yang ada, maka kondisi ini akan menyulitkan PT ADM untuk mempercepat atau berkembang lebih jauh. Selain itu, supplier yang kurang kompeten akan mengakibatkan hasil produksi yang tidak maksimal, harga yang tidak sesuai dengan pasar yang ada. Pada akhirnya, hal tersebut akan berdampak pada reputasi PT ADM.

\section{METODE}

Gambar 1 menjelaskan langkah-langkah penelitian ini dilakukan, mulai dari tahap identifikasi masalah dengan melakukan interview atau diskusi di bagian Procurement pada PT ADM yang merasakan permasalahan yang sekarang, lalu dilanjutkan dengan melakukan menyebarkan lembar pertanyaan yang diberikan hanya kepada 5 orang yang mempunyai kompetensi pada bidang ini. Langkah awal adalah dengan mengetahui standar kebutuhan atau standar yang diperlukan oleh perusahaan sebagai kriteria awal sebagai supplier di PT ADM, dan setelah mendapatkan paramater tersebut maka parameter tersebut akan menjadi parameter pada AHP.

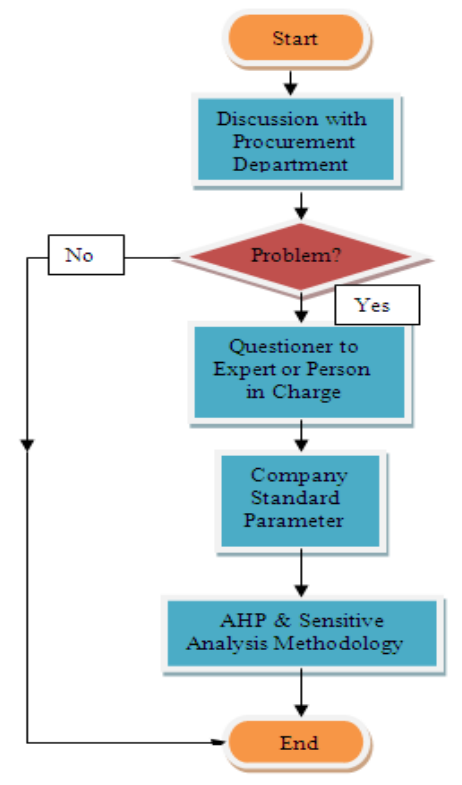

Gambar 1 Diagram Metode Penelitian 
Metode Pemilihan supplier yang sudah dikenal ada cukup banyak. Teori-teori yang berkaitan dengan pemilihan supplier juga sudah banyak terdapat di Internet maupun jurnal dan buku. Metode pemilihan supplier yang dikenal sampai saat ini yaitu metode categorical, metode weight point, metode cost ratio, dan metode Analytical Hierarcy Process (AHP). Setiap metode memiliki kelebihan dan kekurangan masing-masing, sehingga metode yang digunakan dapat menyesuaikan dengan SOP yang sudah ada pada perusahaan.

Setiap metode pemilihan supplier bergantung pada kriteria yang sudah ditentukan oleh masing-masing perusahaan. Masing-masing perusahaan memiliki kriteria yang berbeda untuk menentukan supplier mana yang berhak dipilih pada saat supplier selection. Terdapat beberapa kriteria yang digunakan dalam pemilihan supplier. Menurut Choy dan Hartley (1996), terdapat 7 faktor yang dapat dijadikan sebagai kriteria pemilihan supplier, yaitu: finance, consistency, realibility, relationship, flexibility, technological capacity, dan services. Pendapat lain juga dikemukakan oleh Fun dan Hung (1997), bahwa ada lima kriteria pemilihan supplier, yaitu: quality, cost, delivery, flexibility, dan responsiveness. Dari banyaknya metode pemilihan supplier, metode AHP menjadi pilihan yang diambil.

AHP (Analytical Hierarcy Process) adalah model pendukung keputusan yang dikembangkan oleh Thomas L. Saaty. Metode ini menyederhanakan masalah yang dihadapi pada saat supplier selection ke dalam suatu hierarki. Menurut Saaty (1993), pengertian dari hierarki adalah representasi dari sebuah masalah dimana terdapat struktur multilevel, kriteria, subkriteria dan seterusnya. Penggunaan metode AHP sering digunakan dibandingkan dengan metode lain karena: struktur yang hierarki sebagai konsekuensi dari kriteria yang dipilih sampai pada subkriteria yang paling dalam, memperhitungkan validitas sampai pada batas toleransi inkonsistensi berbagai kriteria dan alternatif yang dipilih oleh pengambil keputusan, dan memperhitungkan daya tahan luaran analisis sensitivitas pengambilan keputusan. Tabel 1 menjelaskan kelebihan dan kekurangan dari metode AHP.

Tabel 1 Metode AHP

\begin{tabular}{|c|c|c|}
\hline No & KELEBIHAN & KEKURANGAN \\
\hline 1 & $\begin{array}{l}A H P \text { membuat permasalahan yang luas menjadi } \\
\text { model yang fleksibel dan mudah dipahami }\end{array}$ & $\begin{array}{l}\text { Ketergantungan model } A H P \text { pada input utama. } \\
\text { Input utama ini berasal dari persepsi seorang ahli } \\
\text { sehingga dalam hal ini melibatkan subjektivitas si } \\
\text { ahli. Selain itu juga model ini tidak berarti apabila } \\
\text { ahli tersebut memberikan penilaian yang keliru. }\end{array}$ \\
\hline 2 & $\begin{array}{l}\text { AHP memecahkan permasalahan yang } \\
\text { kompleks melalui pendekatan sistem dan } \\
\text { pengintegrasian secara deduktif. }\end{array}$ & $\begin{array}{l}\text { Metode } A H P \text { ini hanya metode matematis tanpa ada } \\
\text { pengujian secara statistik sehingga tidak ada batas } \\
\text { kepercayaan dari kebenaran model yang dibentuk. }\end{array}$ \\
\hline 3 & $\begin{array}{l}\text { AHP dapat digunakan pada elemen-elemen } \\
\text { yang saling bebas dan tidak memerlukan } \\
\text { hubungan linier }\end{array}$ & \\
\hline 4 & $\begin{array}{l}\text { AHP mewakili pemikiran yang alamiah yang } \\
\text { cenderung mengelompokkan elemen sistem } \\
\text { kedalam tingkatan yang berbeda dari masing- } \\
\text { masing tingkatan yang berisi elemen yang } \\
\text { serupa. }\end{array}$ & \\
\hline 5 & $\begin{array}{l}\text { AHP menyediakan skala pengukuran dan } \\
\text { metode untuk mendapatkan prioritas }\end{array}$ & \\
\hline 6 & $\begin{array}{l}\text { AHP mempertahankan konsistensi logis dalam } \\
\text { penilaian yang digunakan untuk menentukan } \\
\text { prioritas. }\end{array}$ & \\
\hline
\end{tabular}

Tahapan yang dilakukan dalam metode AHP antara lain sebagai berikut. Pertama, mendefinisikan masalah dan menentukan solusi yang diinginkan. Kedua, membuat struktur hierarki yang diawali dengan tujuan utama. Ketiga, membuat matriks perbandingan berpasangan yang menggambarkan kontribusi relatif atau pengaruh setiap elemen terhadap tujuan atau kriteria yang 
setingkat di atasnya. Keempat, mendefinisikan perbandingan berpasangan sehingga memperoleh jumlah penilaian seluruhnya sebanyak $n \times[(n-1) / 2]$ buah, dengan $n$ adalah banyaknya elemen yang dibandingkan, Kelima, menghitung nilai eigen dan menguji konsistensinya. Keenam, mengulangi langkah 3, 4, dan 5 untuk seluruh tingkat hierarki. Ketujuh, menghitung vektor eigen dari setiap matriks perbandingan berpasangan. Kedelapan, memeriksa hasil dari konsistensi hierarki.

Kemudian, sejalan dengan tahapan keempat dari AHP tersebut, terdapat skala perbandingan berpasangan dan maknanya yang diperkenalkan oleh Saaty, yang dijelaskan melalui Tabel 2 berikut.

Tabel 2 Intensitas Kepentingan AHP

\begin{tabular}{cl}
\hline Intensitas Kepentingan & \multicolumn{1}{c}{ Keterangan } \\
\hline 1 & $\begin{array}{l}\text { Kedua elemen sama pentingnya, dua elemen memiliki pengaruh yang sama } \\
\text { besar } \\
\text { Elemen yang satu sedikit lebih penting daripada elemen yang lainnya, } \\
\text { pengalaman dan penilaian sedikit mendukung satu elemen dibandingkan elemen } \\
\text { yang lainnya }\end{array}$ \\
5 & $\begin{array}{l}\text { Elemen yang satu lebih penting daripada elemen yang lainnya, pengalaman dan } \\
\text { penilaian sedikit mendukung satu elemen dibandingkan elemen yang lainnya } \\
\text { Satu elemen jelas lebih mutlak penting daripada elemen lainnya, satu elemen } \\
\text { yang kuat didukung dan dominan terlihat dalam praktek. } \\
\text { Satu elemen mutlak penting daripada elemen - elemen lainnya. } \\
\text { Nilai-nilai antara dua nilai pertimbangan-pertimbangan yang berdekatan. } \\
\text { Jika untuk elemen i mendapat satu angka bila dibandingkan dengan elemen j, } \\
\text { maka j mempunyai nilai kebalikannya bila dibandingkan dengan i. }\end{array}$ \\
\hline
\end{tabular}

Sehubungan dengan penggunaan metode AHP yang menghasilkan kriteria dengan masingmasing prioritasnya, keberadaan analisis sensitivitas menjadi diperlukan ketika adanya informasi tambahan. Sehingga, decision maker bisa mengubah penilaiannya dalam suatu pembuatan part. Akibat dari perubahan ini adalah adanya perubahan urutan prioritas.

Dobrica dan Niemela (2002) mengemukakan tentang adanya pertanyaan mengenai sensitivitas dari arsitektur metode evaluasi. Hal ini terjadi karena kebanyakan metode evaluasi bersifat kualitatif. Namun demikian, metode AHP adalah salah satu metode kuantitatif untuk mengevaluasi suatu kriteria. Metode AHP memiliki kecendurangan untuk bisa dihitung sensitivitas bobot kriteria yang sudah dihasilkan sebelumnya. Pada Svahnberg et al. (2003), untuk prioritas terakhir yang dihasilkan metode AHP, analisis sensitivitas bisa dilakukan.

Untuk melakukan filterisasi, maka diperlukan tolok ukur. Dengan demikian berdasarkan metodologi AHP dari keseluruhan kuesioner terdapat 5 jenis pertanyaan (kriteria) yang di - pairwaise. Pairwaise dilakukan sampai pada subkriteria terakhir. Proses perhitungan AHP terdiri atas beberapa tahapan antara lain sebagai berikut.

\section{Mencari Mean}

Berikut ini adalah perhitungan dari hasil penggabungan penilaian kuesioner, dengan nilai mean didapat dengan cara:

$\mathbf{x} \sqrt{\mathbf{R} 1+R 2+R 3+R 4+R 5}_{\text {. }}$

" $\mathrm{x}$ " mewakili jumlah responden.

Skala menggunakan skala Saaty antara 1 sampai dengan 9 dengan nilai sebagai berikut: (1) sama penting, (2) rata rata, (3) sedikit lebih penting, (4) rata rata, (5) lebih penting, (6) rata rata, (7) sangat penting, (8) rata rata, (9) mutlak sangat penting. 
Tabel 3 Contoh Hasil Perhitungan Pairwaise

\begin{tabular}{|c|c|c|c|c|c|c|c|c|c|c|c|c|c|}
\hline \multicolumn{2}{|c|}{ Pairwaise main criteria } & \multicolumn{6}{|c|}{ Points } & R1 & $\mathrm{R} 2$ & R3 & R4 & R5 & Mean \\
\hline Management & Engineering & 12 & \begin{tabular}{l|l}
2 & 3 \\
\end{tabular} & 4 & 5 & \begin{tabular}{l|l|}
5 & 7 \\
\end{tabular} & 8 & 1 & 0,2 & 9 & 5 & 1 & 1,745 \\
\hline Management & Quality & \begin{tabular}{|l|l|l}
1 & 2 \\
\end{tabular} & \begin{tabular}{l|l}
2 & 3 \\
\end{tabular} & 4 & 5 & \begin{tabular}{ll|}
6 & 7 \\
\end{tabular} & 8 & 0,333 & 0,2 & 1 & 0,333 & 1 & 1,234 \\
\hline Management & Production \& Logistic control & 122 & \begin{tabular}{l|l}
2 & 3 \\
\end{tabular} & 4 & 5 & 67 & 8 & 1 & 1 & 1 & 0,333 & 0,333 & 1,297 \\
\hline Management & Experience & 125 & \begin{tabular}{l|l}
2 & 3 \\
\end{tabular} & 4 & 5 & \begin{tabular}{l|l}
6 & 7 \\
\end{tabular} & 8 & 1. & 0,333 & 9 & 5 & 0,111 & 1,729 \\
\hline Management & Environment \& Sertification & 122 & \begin{tabular}{l|l|l}
2 & 3 \\
\end{tabular} & 4 & 5 & \begin{tabular}{l|l}
6 & 7 \\
\end{tabular} & 8 & 1 & 0,333 & 9 & 3 & 0,333 & 1,687 \\
\hline Engineering & Quality & \begin{tabular}{|l|l|l}
1 & 2 \\
\end{tabular} & \begin{tabular}{l|l}
2 & 3 \\
\end{tabular} & 4 & 5 & \begin{tabular}{l|l|}
6 & 7 \\
\end{tabular} & 8 & 1 & 0,333 & 0,111 & 0,2 & 1 & 1,215 \\
\hline Engineering & Production \& Logistic control & 112 & \begin{tabular}{l|l}
2 & 3 \\
\end{tabular} & 4 & 5 & \begin{tabular}{l|l}
6 & 7 \\
\end{tabular} & 8 & 1 & 3 & 1 & 0,2 & 0,333 & 1,408 \\
\hline Engineering & Experience & 112 & \begin{tabular}{l|l}
2 & 3 \\
\end{tabular} & 4 & 5 & \begin{tabular}{l|l|}
6 & 7 \\
\end{tabular} & 8 & 5 & 0,333 & 9 & 1 & 0,111 & 1,729 \\
\hline Engineering & Environment \& Sertification & \begin{tabular}{l|l}
1 & 2 \\
\end{tabular} & \begin{tabular}{l|l}
2 & 3 \\
\end{tabular} & 4 & 5 & $\begin{array}{ll}6 & 7 \\
\end{array}$ & 8 & 3 & 3 & 9 & 1 & 0,333 & 1,748 \\
\hline Quality & Production \& Logistic control & 12 & \begin{tabular}{l|l}
2 & 3 \\
\end{tabular} & 4 & 5 & 67 & 8 & 5 & 5 & 1 & 0,333 & 0,333 & 1,635 \\
\hline Quality & Experience & \begin{tabular}{|l|l|l}
1 & 2 \\
\end{tabular} & \begin{tabular}{l|l}
2 & 3 \\
\end{tabular} & 4 & 5 & \begin{tabular}{l|l|}
6 & 7 \\
\end{tabular} & 8 & 9 & 5 & 9 & 5 & 0,111 & 1,949 \\
\hline Quality & Environment \& Sertification & 122 & \begin{tabular}{l|l}
2 & 3 \\
\end{tabular} & 4 & 5 & 67 & 8 & 9 & 5 & 9 & 5 & 1 & 1,961 \\
\hline Production \& Logistic control & Experience & \begin{tabular}{l|l}
1 & 2 \\
\end{tabular} & $\begin{array}{lll}2 & 3 \\
\end{array}$ & 4 & 5 & $\begin{array}{ll}6 & 7 \\
\end{array}$ & & 5 & 1 & 9 & 5 & 0,111 & 1,823 \\
\hline Production \& Logistic control & Environment \& Sertification & \begin{tabular}{l|l}
1 & 2 \\
\end{tabular} & \begin{tabular}{l|l}
2 & 3 \\
\end{tabular} & 4 & 5 & $\begin{array}{ll}6 & 7 \\
\end{array}$ & 8 & 5 & 1 & 9 & 5 & 9 & 1,961 \\
\hline Experience & Environment \& Sertification & \begin{tabular}{|l|l|l|}
1 & 2 \\
\end{tabular} & \begin{tabular}{l|l}
2 & 3 \\
\end{tabular} & 4 & & $\begin{array}{ll}6 & 7 \\
\end{array}$ & 8 & 0,333 & 1 & 9 & 3 & 9 & 1,861 \\
\hline
\end{tabular}

Tabel 3 membandingkan antara satu komponen dengan komponen yang lain. Komponen ini menjadi dasar penilaian calon supplier oleh divisi Purchasing. Ambil contoh pairwaise sebagai berikut: antara manajemen dengan engineering; setiap responden memiliki jawaban yang berbedabeda, untuk responden 1 (R1) memilih 1, artinya menurut yang bersangkutan, manajement dan engineering sama-sama memiliki peran yang penting; Untuk R2, mengapa 0,2 (1/5), karena responden 2 menganggap engineering (1) lebih penting dibandingkan manajemen (5) (nilai kebalikan 1/5). Proses pairwaise ini dilakukan sampai dengan subkriteria paling terakhir.

\section{Menggabungkan Hasil Kuesioner}

Penggabungan hasil kuesioner dilakukan dengan memasukkan nilai mean dari dua kriteria yang dibandingkan ke dalam sebuah kolom. Jika yang dibandingkan adalah dua kriteria yang sama, berikan nilai 1. Sedangkan jika nilai mean dari dua kriteria yang dibandingkan adalah kebalikannya, nilai yang ditulis adalah $1 /$ mean dari dua kriteria yang dibandingkan. Berikut ini adalah tabel perhitungan tahapan kedua untuk pairwaise kriteria utama:

Tabel 4 Perhitungan Pairwise Tahap 2

\begin{tabular}{|c|c|r|r|r|r|r|}
\hline Pairwaise main criteria & Management & Engineering & Quality & $\begin{array}{c}\text { Production } \\
\text { \& Logistic } \\
\text { control }\end{array}$ & Experience & $\begin{array}{c}\text { Environment \& } \\
\text { Sertification }\end{array}$ \\
\hline Management & 1 & 1,745432277 & 1,23446 & 1,29674 & 1,72884 & 1,687067738 \\
\hline Engineering & 0,572923976 & 1 & 1,21469 & 1,40798 & 1,72884 & 1,748296004 \\
\hline Quality & 0,810073753 & 0,823252599 & 1 & 1,63452 & 1,94884 & 1,961009057 \\
\hline Production \& Logistic control & 0,771162165 & 0,710235921 & 0,6118 & 1 & 1,82258 & 1,961009057 \\
\hline Experience & 0,578422984 & 0,578422984 & 0,51313 & 0,54867 & 1 & 1,861189996 \\
\hline Environment \& Sertification & 0,592744427 & 0,57198552 & 0,50994 & 0,50994 & 0,53729 & 1 \\
\hline Jumlah & 4,325327305 & 5,429329302 & 5,08402 & 6,39786 & 8,76639 & 10,21857185 \\
\hline
\end{tabular}

Sebagai contoh, nilai pada mean pairwaise management dan engineering adalah 1,74543 . Jika dibalik, nilai mean pairwaise engineering dan management adalah 1/1,74543 (0,57292). Demikian seterusnya lihat pada Tabel 4. 


\section{Normalisasi Matrix}

Tahapan selanjutnya normalisasi matrix. Normalisasi matrix dilakukan dengan cara menjumlahkan semua hasil dari mean yang berasal dari tahapan sebelumnya, kemudian mencari weight dari setiap kriteria dengan cara membagi total mean dengan jumlah kriteria yang ada pada proses pairwaise yang sedang dikerjakan. Setelah mendapatkan weight masing-masing kriteria, maka ditentukan kriteria yang memiliki weight dari yang tertinggi sampai terendah. Tabel 5 menunjukkan perhitungan normalisasi matrix.

Tabel 5 Perhitungan Normalisasi Matrix

\begin{tabular}{|c|c|c|c|c|c|c|c|c|}
\hline Pairwaise main criteria & Management & Enginaering & Quality & \begin{tabular}{|c|} 
Production \& \\
Logistic \\
control \\
\end{tabular} & Experience & $\begin{array}{l}\text { Environment } \\
\text { \& Sertification }\end{array}$ & Total & Weight \\
\hline Management & 0,231196376 & 0,32148212 & 0,24281095 & 0,20268413 & 0,1972122 & 0,16509819 & 1,36048 & 0,22675 \\
\hline Engineering & 0,132457947 & 0,18418481 & 0,23892396 & \begin{tabular}{|l|}
0,220071 \\
\end{tabular} & 0,1972122 & 0,17109005 & 1,14394 & 0,19066 \\
\hline Quality & 0,187286116 & 0,15163063 & 0,19669477 & 0,25547877 & 0,22230791 & 0,19190637 & 1,2053 & 0,20088 \\
\hline Production \& Logistic control & 0,178289898 & 0,13081467 & 0,12033819 & 0,15630233 & 0,20790576 & \begin{tabular}{|l|}
0,19190637 \\
\end{tabular} & 0,98556 & 0,16426 \\
\hline Experience & 0,133729298 & 0,10653673 & 0,10092929 & 0,08575871 & 0,11407207 & 0,18213798 & 0,72316 & 0,12053 \\
\hline Environment \& Sertification & 0,137040364 & 0,10535105 & 0,10030284 & 0,07970505 & 0,06128986 & 0,09786103 & 0,58155 & 0,09693 \\
\hline Jumlah & 1 & \begin{tabular}{|r|}
1 \\
\end{tabular} & 1 & 1 & 1 & 1 & & \\
\hline w1 & \multicolumn{8}{|c|}{0,226747327 management } \\
\hline w2 & \multicolumn{8}{|c|}{0,200884095 quality } \\
\hline w3 & \multicolumn{8}{|c|}{0,190656663 engineering } \\
\hline w4 & \multicolumn{8}{|c|}{0,164259537 production \& Logistic control } \\
\hline w5 & \multicolumn{8}{|c|}{ 0,120527346 experience \& sertification } \\
\hline w6 & \multicolumn{8}{|c|}{0,096925032 environment \& sertification } \\
\hline
\end{tabular}

Untuk mendapatkan nilai 0,2311 (Pairwaise management dengan management) didapat dari perbandingan mean management dibandingkan dengan total mean dari perhitungan mean management sebelumnya ( 1 / 4,3253273). Lakukan perbandingan nilai mean ini sampai dengan pairwaise main criteria terakhir. Pada gambar, dilakukan proses penentuan kriteria yang memiliki nilai weight $(w)$ yang paling besar sampai dengan yang paling kecil. Kriteria yang memiliki besar weight yang paling besar diberikan simbol w1, berturut turut sampai kriteria dengan weight terkecil disimbolkan dengan w6. Pada normalisasi matrix, yang memiliki nilai weight paling besar adalah management dan yang memiliki nilai weight paling kecil adalah kriteria environment and sertification.

\section{Menghitung Konsistensi}

Level selanjutnya adalah menghitung nilai konsistensi dari setiap kriteria. Caranya adalah dengan mengalikan hasil normalisasi matrix dengan nilai weight sesuai dengan kriteria yang sedang dihitung. Untuk mendapatkan hasil akhir dari konsistensi setiap kriteria, maka nilai total yang sudah dihitung kemudian dibagi dengan weight masing-masing kriteria.

Langkah terakhir adalah dengan mencari nilai Ci (Consistency Index) dan $\mathrm{Cr}$ (Consistency Ratio) dari setiap perhitungan. Langkah awal adalah dengan mencari amaks. Cara mencari $\alpha$ maks dengan membagi total dari hasil akhir konsistensi semua kriteria dengan jumlah kriteria yang sedang dihitung. Kemudian untuk menentukan $\mathrm{Ci}$ dengan cara ( $\alpha$ maks - jml kriteria) / (kriteria - 1). Setelah menemukan nilai $\mathrm{Ci}$, maka selanjutnya adalah menentukan nilai $\mathrm{Cr}$ yang didapat dengan cara membagi nilai $C i$ dengan nilai $R i$. (RandomConsistencyIndex). Nilai $R i$ didapat berdasarkan berapa jumlah kriteria yang dibandingkan. Besaran $R i$ bisa dilihat dari tabel seperti berikut ini. 
Tabel 6 Random Consistency Index

\begin{tabular}{|l|r|r|r|r|r|r|r|r|r|r|r|r|r|r|r|}
\hline OM & 1 & 2 & 3 & 4 & 5 & 6 & 7 & 8 & 9 & 10 & 11 & 12 & 13 & 14 & 15 \\
\hline $\mathrm{RI}$ & 0 & 0 & 0,58 & 0,90 & 1,12 & 1,24 & 1,32 & 1,41 & 1,45 & 1,49 & 1,51 & 1,48 & 1,56 & 1,57 & 1,59 \\
\hline
\end{tabular}

$O M$ merupakan jumlah kriteria yang dibandingkan, sedangkan $R i$ adalah besaran dari Random Consistency Index-nya. Misalkan seperti pada Level 5 pairwaisemainkriteria dibawah ini, jumlah kriteria yang dibandingkan ada 6, maka nilai $R i$ yang dipakai adalah 1,24.

Tabel 7 Tabel Pairwaise

\begin{tabular}{|c|r|r|r|r|r|r|r|}
\hline Pairwaise main criteria & Management & Engineering & Qvality & $\begin{array}{l}\text { Prodvction \& } \\
\text { Logistic } \\
\text { control }\end{array}$ & Experience & $\begin{array}{c}\text { Environment \& } \\
\text { Sertification }\end{array}$ & Total \\
\hline Management & 0,226747327 & 0,332778294 & 0,24798248 & 0,21300259 & 0,20837233 & 0,163519094 & 1,392402 \\
\hline Engineering & 0,12990898 & 0,190656663 & 0,24401271 & 0,23127461 & 0,20837233 & 0,169453646 & 1,173679 \\
\hline Quality & 0,183682058 & 0,156958594 & 0,2008841 & 0,26848495 & 0,2348882 & 0,190070866 & 1,234969 \\
\hline Production \& Logistic contro1 & 0,174858959 & 0,135411211 & 0,12290122 & 0,16425954 & 0,21967104 & 0,190070866 & 1,007173 \\
\hline Experience & 0,131155865 & 0,110280196 & 0,10307894 & 0,09012461 & 0,12052735 & 0,1803959 & 0,735563 \\
\hline Environment \& Sertification & 0,134403214 & 0,109052851 & 0,10243915 & 0,08376276 & 0,06475822 & 0,096925032 & 0,591341 \\
\hline
\end{tabular}

\begin{tabular}{|c|r|r|r|}
\hline Pairwaise main criteria & \multicolumn{1}{|l|}{ Total } & Weight & Result \\
\hline Management & 1,392402111 & 0,226747327 & 6,14076528 \\
\hline Engineering & 1,17367894 & 0,190656663 & 6,15598175 \\
\hline Quality & 1,234968763 & 0,200884095 & 6,1476682 \\
\hline Production \& Logistic contro1 & 1,007172833 & 0,164259537 & 6,13159424 \\
\hline Experience & 0,735562855 & 0,120527346 & 6,10287111 \\
\hline Environment \& Sertification & 0,591341224 & 0,096925032 & 6,10101655 \\
\hline \multicolumn{3}{|c|}{ Total result } & 36,7798971 \\
\hline \multicolumn{2}{|c|}{$\alpha$ Maks } & 6,12998285 \\
\hline
\end{tabular}

Pada tahap Filtering Supplier, ditentukan PT ADM menitikberatkan 6 aspek yang didapat dari perhitungan dari hasil jawaban pertanyaan dari pihak internal (yang mempunyaikemampuan/expert) terkait. Dari proses tersebut, maka 6 aspek yang menjadi penentu atau tolok ukur dari Supplier, yaitu: management, engineering, quality, production and logistic control, experiences, environment and certification. PT ADM tetap menyadari bahwa aspek lainnya juga berperan penting dalam penilaian supplier. Akan tetapi, 6 aspek tersebut merupakan supplier yang diharapkan dapat memberikan kontribusi yang baik pada PT ADM.

Setelah proses filtering yang menjadi proses awal tidak serta merta Supplier dapat langsung menjadi penyedia barang, untuk menjadikan hasil lebih akurat maka langkah selanjutnya dilakukan proses Sensitifity Analysis. Proses analisis sensitivitas dapat dilakukan pada saat akhir perhitungan AHP, yang pada perhitungan akhir belum didapat calon supplier yang benar-benar sesuai dengan keinginan management ADM. Analisis sensitivitas dapat dilakukan dengan mengubah bobot kriteria yang sudah ada. Bisa dinaikkan atau diturunkan nilainya, tergantung pada kebijakan management untuk masing-masing pengadaan part yang diinginkan.

Setelah mengenal dan mengetahui secara detail proses yang sudah berjalan pada divisi purchasing, maka dapat disimpulkan bahwa ada beberapa hal yang bisa dilakukan untuk memperbaiki sistem yang sudah berjalan. Usulan business process yang hendak diberikan pada divisi Purchasing ADM akan dijelaskan pada rich picture berikut ini. 


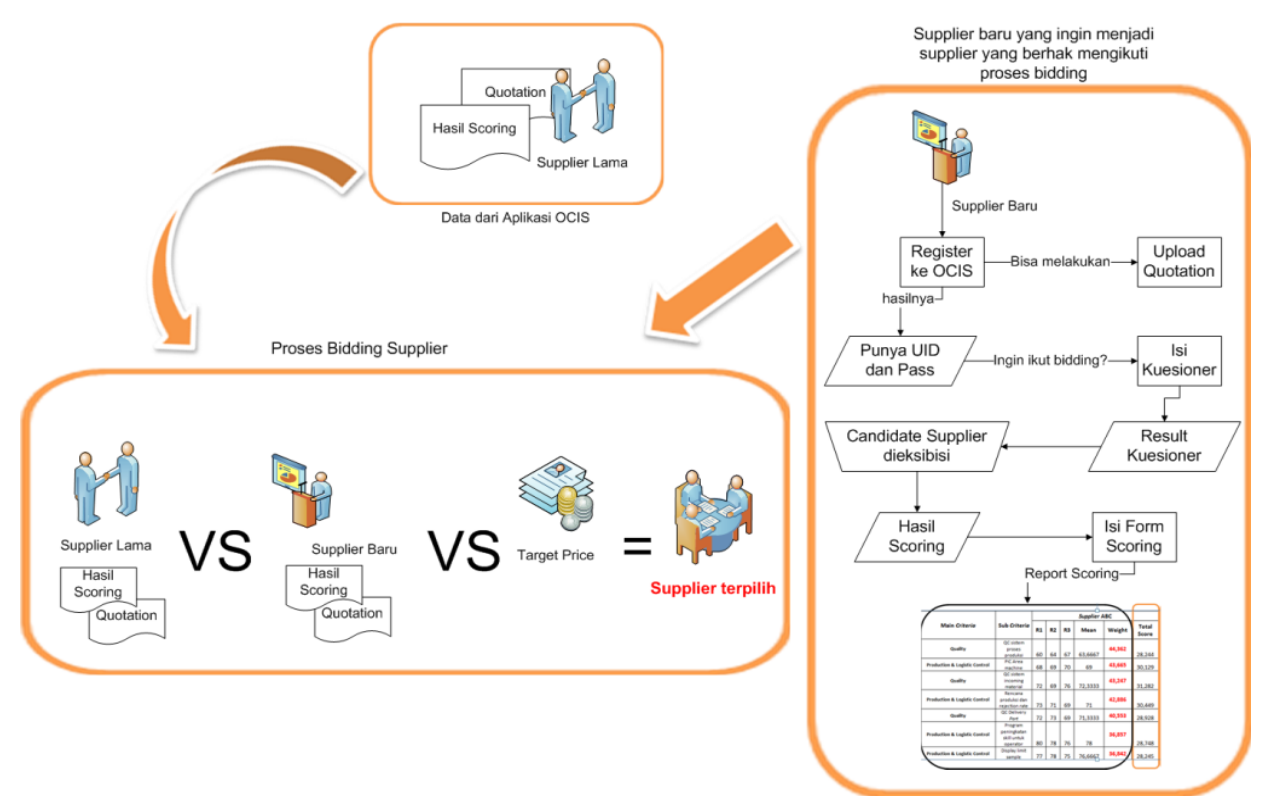

Gambar 2 Rich Picture Usulan Bisnis Proses

Gambar 2 menjelaskan bagaimana usulan business process kami untuk membantu proses bidding supplier. Pada dasarnya baik supplier lama maupun supplier baru dapat mengikuti proses bidding, asalkan setiap supplier sudah memiliki 2 komponen yaitu score kriteria dan harga yang didapat dari quotation yang mereka upload. Bagi supplier baru yang belum memiliki score kriteria dan belum meng-uploadquotation dari part yang hendak dijadikan bahan bidding, maka supplier yang bersangkutan perlu untuk melakukan registrasi ke aplikasi OCIS yang pada bagian registrasi tersebut, supplier baru menginputkan data perusahaan dan sekaligus membuat username dan password-nya. Setelah mempunyai username dan password maka selanjutnya supplier dapat meng-upload quotation ke OCIS lalu mengisi form kuesioner. Ketika sudah melakukan pengisian kuesioner, supplier akan diminta untuk menunggu sampai waktu yang ditentukan untuk pengumuman apakah supplier tersebut masuk pada tahap selanjutnya, yaitu tahap eksibisi. Untuk supplier yang masuk tahap eksibisi, maka admin PUD akan berkunjung pada perusahaan supplier masing - masing dan melakukan penilaian sesuai dengan form scoring yang sudah disediakan di sistem. Ketika semua proses eksibisi ke semua candidate supplier sudah dilakukan, maka hasilnya adalah supplier baru akan memiliki nilai scoring kriteria yang menjadi bahan untuk proses akhir, yaitu bidding supplier.

Pada proses bidding supplier, ada beberapa hal yang akan di-compare dengan menggunakan sistem. Adapun yang akan dijadikan sebagai bahan compare adalah scoring kriteria, harga yang berasal dari quotation yang sudah di-upload, dan target price yang sebelumnya sudah disediakan oleh admin PUD sebagai bahan pertimbangan. Proses pemilihan supplier dibantu dengan adanya analisis sensitivitas, jika terjadi suatu kondisi ketika ketiga komponen yang dibandingkan (nilai, penawaran harga, dan target price) tidak memenuhi kriteria yang diinginkan (nilai terbaik dengan penawaran harga yang paling mendekati target price). Analisis sensitivitas membantu pembuat keputusan untuk dapat melakukan analisis dengan mengubah prioritas kriteria sesuai dengan kebutuhan dari pengadaan part tersebut. Hasil akhir dari proses ini adalah terpilihnya satu supplier yang menjadi supplier yang dipilih untuk bekerja sama dengan PT ADM untuk menyediakan part demi membantu proses produksi. 


\section{HASIL DAN PEMBAHASAN}

Gambaran rancangan proses pemilihan supplier yang menjadi subsistem dari OCIS yang sudah dimiliki dapat dilihat pada Gambar 3. Dengan demikian dapat dikatakan proses akan menjadi sangat efisien dan efektif. Pada gambar dapat dilihat bagi supplier yang ingin mendaftar dapat langsung mendaftar via web. Kemudian sistem akan secara langsung melakukan filterisasi dengan metode AHP menggunakan parameter yang telah ditentukan oleh perusahaan, sehingga hanya supplier yang terpilih yang kemudian akan dilakukan filterisasi lagi berdasarakan kebutuhan proyek dengan analisis sensitivitas. Akhirnya, beberapa supplier yang kemudian dapat ikut masuk dalam proses bidding pada sistem OCIS.

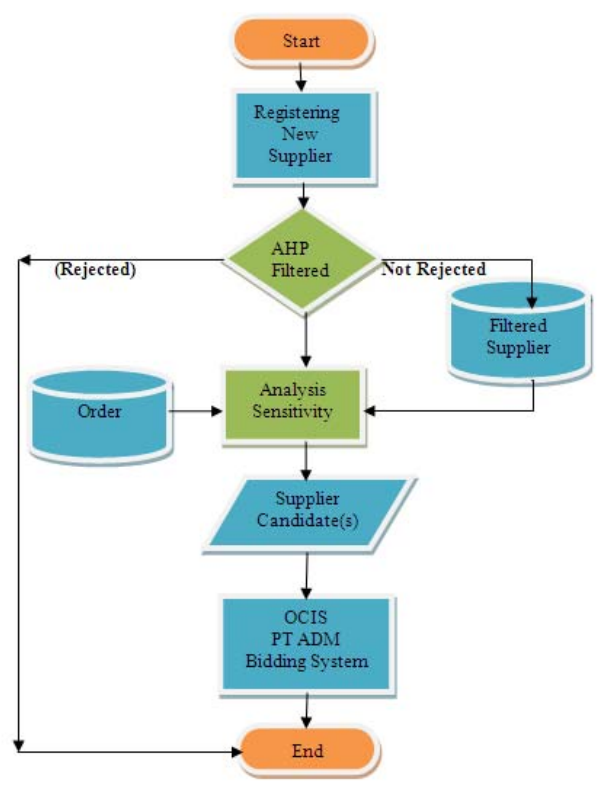

Gambar3 Diagram Hasil Rancangan

Tabel 8 Contoh Tabel Hasil Scoring Supplier

\begin{tabular}{|c|c|c|c|c|c|c|c|c|c|c|c|c|c|}
\hline \multirow[b]{2}{*}{ Main Criteria } & \multirow[b]{2}{*}{ Sub Criteria } & \multicolumn{6}{|c|}{ Supplier ABC } & \multicolumn{6}{|c|}{ Supplier XYZ } \\
\hline & & R1 & R2 & R3 & Mean & Weight & $\begin{array}{l}\text { Total } \\
\text { Score }\end{array}$ & R1 & R2 & R3 & Mean & Weight & $\begin{array}{l}\text { Total } \\
\text { Score }\end{array}$ \\
\hline Quality & $\begin{array}{c}\text { QC sistem } \\
\text { proses } \\
\text { produksi }\end{array}$ & 60 & 64 & 67 & 63,6667 & 44,362 & 28,244 & 72 & 69 & 76 & 72,33 & 44,362 & 32,088 \\
\hline Production \& Logistic Control & $\begin{array}{l}\text { PIC Area } \\
\text { machine }\end{array}$ & 68 & 69 & 70 & 69 & 43,665 & 30,129 & 73 & 71 & 69 & 71 & 43,665 & 31,002 \\
\hline Quality & $\begin{array}{l}\text { QC sistem } \\
\text { incoming } \\
\text { material } \\
\end{array}$ & 72 & 69 & 76 & 72,3333 & 43,247 & 31,282 & 72 & 73 & 69 & 71,33 & 43,247 & 30,85 \\
\hline Production \& Logistic Control & $\begin{array}{c}\text { Rencana } \\
\text { produksi dan } \\
\text { rejection rate }\end{array}$ & 73 & 71 & 69 & 71 & 42,886 & 30,449 & 80 & 78 & 76 & 78 & 42,886 & 33,451 \\
\hline Quality & $\begin{array}{c}\text { QC Delivery } \\
\text { Part }\end{array}$ & 72 & 73 & 69 & 71,3333 & 40,553 & 28,928 & 77 & 78 & 75 & 76,67 & 40,553 & 31,09 \\
\hline Production \& Logistic Control & $\begin{array}{c}\text { Program } \\
\text { peningkatan } \\
\text { skill untuk } \\
\text { operator } \\
\end{array}$ & 80 & 78 & 76 & 78 & 36,857 & 28,748 & 70 & 71 & 72 & 71 & 36,857 & 26,168 \\
\hline Production \& Logistic Control & $\begin{array}{c}\text { Display limit } \\
\text { sample }\end{array}$ & 77 & 78 & 75 & 76,6667 & 36,842 & 28,245 & 68 & 70 & 70 & 69,33 & 36,842 & 25,544 \\
\hline
\end{tabular}

Seperti telah dikatakan atau dapat dilihat pada gambar setelah proses AHP, maka dilakukan proses analisis sensitivitas. Berikut ini merupakan tampilan contoh proses perhitungan analisis sensitivitas terhadap 3 terpilih berdasarkan AHP. Tahap ini menitikberatkan pada kebutuhan tiap proyek yang menjadi titik berat. Dengan demikian, prioritas akhir sebuah kriteria dapat berubah: 
Tabel 9 Contoh Tabel Pemilihan Supplier Berdasarkan Prioritas

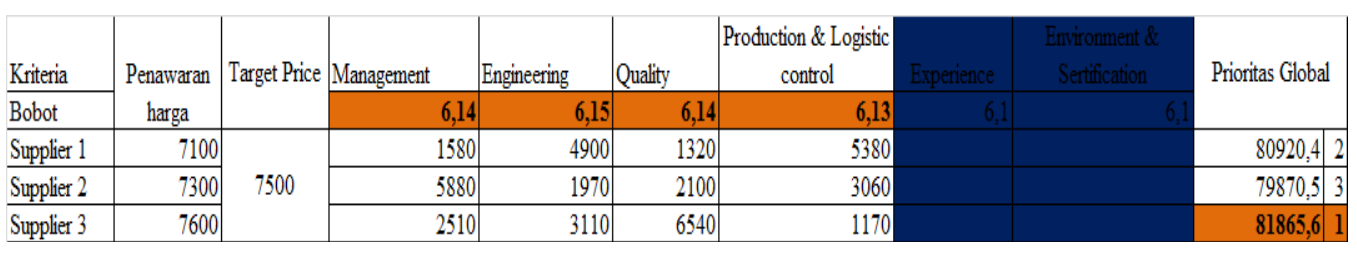

Tabel dapat dijelaskan, menampilkan bobot main kriteria dan perolahan nilai setiap supplier terpilih sesuai dengan main kriteria. Nilai dari prioritas global didapat dari perhitungan sebagai berikut:
a. $80920,4=(1580 * 6,14)+(4900 * 6,15)+(1320 * 6,14)+(5380 * 6,13)$
b. $79870,5=(5880 * 6,14)+(1970 * 6,15)+(2100 * 6,14)+(3060 * 6,13)$
c. $\mathbf{8 1 8 6 5 , 6}=(2510 * 6,14)+(3110 * 6,15)+(6540 * 6,14)+(1170 * 6,13)$

Dari proses perhitungan, yang menjadi prioritas pertama adalah Supplier 3, dengan penawaran harganya adalah 7600. Analisis sensitivitas dapat dilakukan dengan melakukan perubahan bobot kriteria tertentu. Sebagai contoh adalah dengan menurunkan bobot kriteria management dari 6,14 menjadi 5. Yang terjadi adalah sebagai berikut:

Tabel 10 Contoh Tabel Pemilihan Supplier Berdasarkan Analisis Sensitivitas

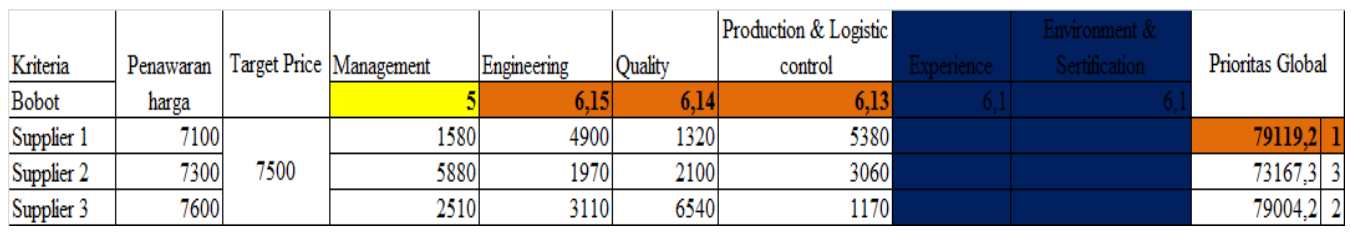

Dari tabel dapat dilihat dengan menggunakan metode Analisis Sensitivitas, maka setiap proyek dapat memilih supplier yang lebih sesuai dengan kebutuhan tiap proyek. Pada tabel dapat dikatakan jika kriteria management tidak menjadi penentu atau bobotnya dipertimbangakan leibih sedikit, supplier 1 dapat dikatakan akan menjadi calon pemenang untuk proyek tersebut.

\section{SIMPULAN}

Penggunaan DSS dengan metode AHP akan sangat membantu perusahaan dalam pemilihan supplier. Proses pemilihan dapat dilakukan dengan cepat dan sesuai dengan standar yang dibutuhkan perusahaan. Ditambah dengan Analisis Sensitivitas, hal itu sangat membantu dalam proses pencarian supplier yang sesuai dengan tujuan dari order. Dengan menggunakan ini maka ketersediaan part dapat berlangsung dengan baik dan mempunyai kualitas seperti yang diharapkan perusahaan; dan yang tidak kalah penting adalah harga dari part yang bersaing. Pengembangan sistem ini masih sangat dimungkinkan untuk digunakan pada hal lain. Intinya, mempercepat proses pengambilan keputusan yang sesuai dengan criteria yang dimiliki perusahaan dan sesuai dengan kebutuhan. 


\section{DAFTAR PUSTAKA}

Anonim. (2011). Company Profile of PT Astra Daihatsu Motor.

Adiwiguna, N. (2012). Sosialisasi OCIS Okt-Nov 2012. Jakarta.

Chamodraks, I., Batis, D., and Martakos, D. (2010). Supplier selection in electronic marketplaces using satisficing and fuzzy AHP. Elsevier Expert Systems with Applications, 37, 490-498.

Choi, T.Y, and Hartley, J. L. (1996). An exploration of supplier selection practices across the supply chain. Journal of Operation Management, 14, 333-343.

Dobrica, L. \& Niemela, E. (2002, Jul). A Survey on software architecture analysis methods. IEEE Transactions on Software Engineering, 28(7), 638-653.

Fun dan Hung. (1997). A new measure for supplier performance evaluation. IIE Transactions, 29(9), 753-758.

GAWS Inti Solusi. (2011). OCIS Manual Desktop v1.2. Jakarta: GAWS Inti Solusi.

Saaty, T. L. (2001). Decision Making for Leaders of the AHP Series.Vol. II.

Svahnberg, M., et al. (2003). A quality-driven decision-support method for identifying software architecture candidates. International Journal of Software Engineering and Knowledge Engineering, 13(5), 547-573.

Ting, Shin-Chan. (2008). An Integrated Approach for Supplier Selection and Purchasing Decisions. VOl. XIII, 116-127.

Zhu, Liming. Aybuke Aurum. Ian Gorton. Ross Jeffery. (2005). Tradeoff and Sensitivity Analysis in Software Architecture Evaluation Using Analytical Hierarchy Process, 13, 357-375. 